\title{
COGNITIVE BIAS AFFECTING DECISION-MAKING IN THE LEGAL PROCESS
}

\author{
Adebola Olaborede \\ LLB LLM LLD
}

Post-Doctoral Fellow; Law, Science and Justice

Research Niche Area, Nelson Mandela School of Law, Faculty of Law, University of Fort Hare

Lirieka Meintjes-van der Walt

BJuris LLB LLM DJuris

Adjunct Professor, Leader of the Law, Science and Justice Research Niche Area, Nelson

Mandela School of Law, Faculty of Law, University of Fort Hare

\begin{abstract}
The big problem, as it is everywhere, is with unconscious bias. I dare say that we all suffer from a degree of unconscious bias, and it can occur in all sorts of manifestations. It is almost by definition an unknown unknown, and therefore extraordinarily difficult to get rid of, or even to allow for. (Lord Neuberger, President of the Supreme Court of the United Kingdom, "Fairness in the Courts: The Best We Can Do", Address to the Criminal Justice Alliance 10th April 2015).
\end{abstract}

\section{SUMMARY}

Several empirical research studies have shown that cognitive bias can unconsciously distort inferences and interpretations made by judges either at the hearing, ruling or sentencing stage of a court trial and this may result in miscarriages of justice. This article examines how cognitive heuristics affects judicial decision-making with seven common manifestations of heuristics such as availability heuristics, confirmation bias, egocentric bias, anchoring, hindsight bias, framing and representativeness. This article contends that the different manifestations of heuristics pose a potentially serious risk to the quality and objectivity of any criminal case, despite the professional legal training and experience of judges and magistrates. Therefore, suggestions on how best to avoid and minimise the effects of cognitive heuristics, especially within South African courts are proffered. These include creating awareness raising, cross-examination and replacement. 


\section{$1 \quad$ INTRODUCTION}

The growing research on, and the scrutiny of, bias within the criminal justice system has shown that judicial decision-makers such as magistrates, judges and fact finders such as the jury ${ }^{1}$ can be susceptible to cognitive bias despite their acquired legal knowledge, training and experience. ${ }^{2}$ Cognitive bias is well-established in psychology and has been described as predispositions and preferences that affect human reasoning, perceptions and judgements. ${ }^{3}$ Cognitive bias involves unconscious or unintentional influences on legal decisions. ${ }^{4}$ This differs from the common-law understanding of bias which involves conscious influences affecting judges or magistrates who have an interest in a case. ${ }^{5}$ This conception of judicial bias, especially in the context of actual bias and apprehension of bias ${ }^{6}$ and how judges' perspectives on factors, such as politics, race, gender, religion and ethnicity etc can influence

1 A jury refers to a group of people chosen from the public to participate in the judicial decision-making process in countries like United States, England and Wales, Canada and Australia etc. This contrasts with the system in South Africa where judges and magistrates (not jury) are used. They are professionally trained for the position and are responsible for the administration of justice in South African courts. See Hornby Oxford Advanced Learner's Dictionary 9ed (2015) 825; Beecher-Monas "Heuristics, Biases, and the Importance of Gatekeeping" 20034 Law Review of Michigan State University Detroit College of Law (L Rev MSU-DCL) 987988.

2 Edmond and Martire "Just Cognition: Scientific Research on Bias and Some Implications for Legal Procedure and Decision-Making" 201982 Modern Law Review (MLR) 633 and Guthrie, Rachlinski and Wistrich "Inside the Judicial Mind" 2001 Cornell Law Faculty Publications Paper 777-830. (The authors argue that the general assumption or expectation that judges can avoid error(s) in judgment is unrealistic due to the problem of cognitive bias or illusions). See also Peer and Gamliel "Heuristics and Biases in Judicial Decisions" 201349 Court Review 114; Gravett "The Myth of Rationality: Cognitive Biases and Heuristics in Judicial Decision-Making" 2017134 The South African Law Journal 5354 Sharp "Cognitive Heuristics and Law - An Interdisciplinary Approach to Better Judicial Decision Making" 199520 Bulletin of the Australian Society of Legal Philosophy 75 and Beecher-Monas 2003 L Rev MSU-DCL 987-1022.

3 Edmond and Martire 2019 MLR 646; The President's Council of Advisors on Science and Technology (PCAST) "Forensic Science in Criminal Courts: Ensuring Scientific Validity of Feature-Comparison Methods" https://obamawhitehouse.archives.gov/sites/default/files/ microsites/ostp/PCAST/pcast_forensic_science_report_final.pdf (accessed 2018-11-02) (PCAST 2016 Report) 31 and Stafford, Holroyd and Scaife "Confronting Bias in Judging: A Framework of Addressing Psychological Biases in Decision Making" (June 2018) https://pdfs.semanticscholar.org/168e/e8355eced41066c11a195092992da37c0176.pdf?_ga $=2.120098568 .1063625548 .1576768096-245500049.1568038155$ (accessed 2019-12-19) $1-20$.

4 Irwin and Real "Unconscious Influences on Judicial Decision-Making: The Illusion of Objectivity" 201642 McGeorge L Rev 2 and Edmond and Martire 2019 MLR 634.

5 Edmond and Martire 2019 MLR 633; Irwin and Real 2016 McGeorge L Rev 2 and Nwauche "A Return to the Manifest Justice Principle: A Critical Examination of 'Reasonable Suspicion/Apprehension of Bias' and 'Real Possibility of Bias' Tests for Judicial Bias in South Africa and England" 20047 PER/PELJ 4.

6 Actual bias is when there is the real likelihood that a judge has an interest in the outcome of a case. Apprehension (or appearance) of bias occurs when parties to a dispute or the public entertain a reasonable suspicion of the likelihood that the judge might be partial and prejudiced in the resolution of a case. In Ebner $v$ Official Trustee in Bankruptcy (2000) HCA 63 par 23. The court notes that: "Bias, whether actual or apprehended connotes the absence of impartiality." See also Nwauche 2004 PER/PELJ 4-7; Malan "Reassessing Judicial Independence and Impartiality Against the Backdrop of Judicial Appointments in South Africa" 201417 PER/PELJ 1965 1998-1999 and Edmond and Martire 2019 MLR 641. 
their decisions, has been dealt with by the courts. ${ }^{7}$ In particular, the South Africa courts have reiterated that the "notion of impartiality" 8 is fundamental to the objectivity and legitimacy of any legal proceedings and judgment. ${ }^{9}$ Impartiality is a standard of conduct which judges or magistrates must adhere to when adjudicating on the facts of a case, contradictory evidence and the relevant principles of law. ${ }^{10}$ The judge or magistrate must make fair and ethical decisions without the influence of biases and prejudices. ${ }^{11}$ Nonetheless, it should be noted that this form of judicial bias is beyond the scope of this article.

The purpose of this article is to examine cognitive bias affecting judicial decision-making. Cognitive bias involves many processes but this article does not attempt to discuss all the processes. Rather, it focuses on the cognitive bias that is produced as a result of heuristics; a strategy or mental shortcuts that people rely on to make complex decisions or judgments simpler. ${ }^{12}$ This is when decisions are made under different situations that

7 Guthrie et al 2001 Cornell Law Faculty Publications Paper 782 and Harris and Sen "Bias and Judging" (2018) https://scholar.harvard.edu/files/msen/files/bias-judging-arps.pdf (accessed 2019-11-03) 1-35.

8 The notion of impartiality resonates with the Latin maxim: Nemo judex in sua causa meaning "no one is a judge in his (or her) own cause" and the right to fair hearing under the general principles of natural justice. Edmond and Martire 2019 MLR 633; Malan 2014 PER/PELJ 1998 and Nwauche 2004 PER/PELJ 1-4.

9 In S v Le Grange (040/2008) [2008] ZASCA 102 par 14, the court states that:

A cornerstone of our legal system is the impartial adjudication of disputes which come before the courts and tribunals. What the law requires is not only that a judicial officer must conduct the trial open-mindedly, impartially and fairly, but that such conduct must be 'manifest to all those who are concerned in the trial and its outcome, especially the accused' ... As far as criminal trials are concerned, the requirement of impartiality is closely linked to the right of an accused person to a fair trial which is guaranteed by $S$ 35(3) of our Constitution.

See also President of Republic of South Africa v South African Rugby Football Union (1999) (4) SA 147 (CC) 177 par 48. The court notes that "[i]t must never be forgotten than an impartial judge is a fundamental prerequisite for a fair trial ..."; $S v$ Basson 2007 (1) SACR 566 (CC) par 26; Livesey v New South Wales Bar Association (1983) 151 CLR 288, 293294 and Republican Party of Minnesota v White 536 US 765 (2002).

10 See, for eg., article 4 of the Code of Judicial Conduct (adopted in terms of $\mathrm{s} 12$ of the Judicial Service Commission Act No. 9 of 1994) for South African judges which states that: "A judge must (a) uphold the independence and integrity of the judiciary and the authority of the courts; (b) maintain an independence of mind in the performance of judicial duties ..." Also, article 14(4)(e) of the South African Judicial Service Commission Amendment Act 20 of 2008 identifies the lack of impartiality as a condition for laying a complaint against a judge and s 165(2) of the South African Constitution Act 108 of 1996 which states that "The courts are independent and subject only to the Constitution and the law, which they must apply impartially and without fear, favour or prejudice." See also Irwin and Real 2016 McGeorge $L$ Rev 1.

11 In Flaherty v National Greyhound Racing Club Ltd [2005] EWCA Civ 1117 par 28 Lord Justice Scott Baker defined bias as "a predisposition or prejudice against one party's case or evidence on an issue for reasons unconnected with the merits of the issue". See also Irwin and Real 2016 McGeorge L Rev 1.

12 Psychologists Amos Tversky and Daniel Kahneman were the first to introduce heuristics and cognitive bias in their study on human judgment and choice. See Tversky and Kahneman "Judgment Under Uncertainty: Heuristics and Biases" 1974185 Science 1124; Peer and Gamliel 2013 Court Review 114; Beecher-Monas 2003 L Rev MSU-DCL 994995; Gravett 2017 The South African Law Journal 54; Guthrie et al 2001 Cornell Law Faculty Publications Paper 780-783; Edmond and Martire 2019 MLR 634; Greene and Ellis 
encourage reliance on limited information instead of on all the relevant information that can be used in decision-making. ${ }^{13}$ Though reliance on heuristics can produce good decisions, it can also result in systematic errors or inaccurate inferences due to the limited information relied upon. ${ }^{14}$

To further the understanding of heuristics and cognitive bias, this article examines seven common manifestations of heuristics that can result in cognitive bias and affect decision-making. These include availability heuristics,,$^{15}$ confirmation bias, ${ }^{16}$ egocentric bias, ${ }^{17}$ anchoring, ${ }^{18}$ hindsight bias, ${ }^{19}$ framing ${ }^{20}$ and representativeness. ${ }^{21}$ Several empirical research studies have demonstrated how these cognitive heuristics affect judges either at the hearing, ruling or sentencing stage of a court trial. ${ }^{22}$ Most of the empirical studies and court cases used to illustrate the effect of heuristics and cognitive bias in judicial decision-making, emanate from the United States of America and Europe. ${ }^{23}$ It seems that there is no empirical evidence to show the influence and extent of the effect of heuristics and cognitive bias on judges in South Africa. ${ }^{24}$ However, the studies conducted (some of which are discussed below) reveal the profound effect of heuristics on judicial decision-making which may result in miscarriages of justice. This article

"Decision Making, in Criminal Justice" (May 2008) https://www.researchgate.net/publication /229737159_Decision_Making_in_Criminal_Justice (accessed 2019-10-27) 3.

13 Gravett 2017 The South African Law Journal 53-54 and Peer and Gamliel 2013 Court Review 114.

14 Gravett 2017 The South African Law Journal 55 and Guthrie, Rachlinski and Wistrich "Judging by Heuristic-Cognitive Illusions in Judicial Decision Making" 200286 Judicature 44.

15 This can occur when a person assesses the probability of an event by the occurrences of its instances recalled. See Tversky and Kahneman 1974 Science 1127.

16 This is when a person seeking to test a hypothesis, beliefs or expectations looks for instances that confirm rather than falsifying instances. See Reese "Techniques for Mitigating Cognitive Biases in Fingerprint Identification" 201259 UCLA Law Review 1252 1260 and Rassin, Eerland and Kuijpers "Let's Find the Evidence: An Analogue Study of Confirmation Bias in Criminal Investigations" 2010 Journal of Investigative Psychology and Offender Profiling (J. Investig. Psych. Offender Profil) 231.

17 This form of heuristics can occur when a judge overestimates his/her abilities. See Guthrie et al 2001 Cornell Law Faculty Publications Paper 780-784.

18 This refers to when a person makes estimates based on an initial reference value. See Guthrie et al 2001 Cornell Law Faculty Publications Paper 784; Hollier "Anchoring Bias in the Courtroom" The Law Project (May 2017) https://www.thelawproject.com.au/insights/ anchoring-bias-in-the-courtroom (accessed 2019-10-21) and Rachlinski, Wistrich and Guthrie "Can Judges Make Reliable Numeric Judgements? Distorted Damages and Skewed Sentences" 201590 Indiana Law Journal 695-739.

19 This can occur when a person overestimates the predictability of past events. Rachlinski "Heuristics and Biases in the Courts: Ignorance or Adaptation" 200079 Oregon Law Review 61.

20 This can occur when a person makes uncertain decisions on whether to settle a case or to proceed to trial. Guthrie et al 2002 Judicature 46.

21 This can occur when a person assesses the probability of certain events and makes categorical judgments. See Guthrie et al 2001 Cornell Law Faculty Publications Paper 805806.

22 See, for eg., Guthrie et al 2001 Cornell Law Faculty Publications Paper 780; Edmond and Martire 2019 MLR 633, Peer and Gamliel 2013 Court Review 114-118; Gravett 2017 The South African Law Journal 53; Sharp 1995 Bulletin of the Australian Society of Legal Philosophy 74-75; Beecher-Monas 2003 L Rev MSU-DCL 995-997.

23 Gravett 2017 The South African Law Journal 53 and 60.

24 Gravett 2017 The South African Law Journal 53. 
reviews the problem of heuristics in judicial decision-making and proffers possible strategies to minimise any negative effects, especially within South African courts.

This article proceeds in four parts. Following the introduction, Part II discusses the role of judges in court proceedings. Part III examines the nature and extent of the influence of cognitive bias and heuristics in judicial decision-making. Part IV provides possible solutions to mitigate the effect of cognitive bias in judicial decision-making.

\section{THE ROLE OF JUDGES}

Judges (and magistrates) are persons appointed to preside over court proceedings. Their appointments are subject to specified minimum criteria. ${ }^{25}$ For instance, judicial appointments in South Africa are subject to the criteria set out in the Constitution ${ }^{26}$ and the supplementary criteria provided by the Judicial Service Commission (JSC). ${ }^{27}$ The criteria are as follows: ${ }^{28}$

In the Constitution:

1 Is the particular applicant an appropriately qualified person?

2 Is he or she a fit and proper person, and

3 Would his or her appointment help to reflect the racial and gender composition of South Africa?

The supplementary criteria include:

1 Is the proposed appointee a person of integrity?

2 Is the proposed appointee a person with the necessary energy and motivation?

3 Is the proposed appointee a competent person?

a) Technically Competent

b) Capacity to give expression to the values of the constitution

4 Is the proposed appointee an experienced person?

a) Technically experienced

b) Experienced in regard to the values and needs of the community

5 Does the proposed appointee possess appropriate potential?

6 Symbolism. What message is given to the community at large by a particular appointment?

Malan 2014 PER/PELJ 1972-1973.

See $\mathrm{s} 174$ and 175 of the South African Constitution.

27 The Judicial Service Commission is an independent body established by virtue of $s 178$ of the South African Constitution and the Judicial Service Act 9 of 1994 to facilitate judicial appointments. Also, the appointment of magistrates is prescribed by Regulations 3(1) of the Magistrate Act No 90 of 1993.

28 Mokgoro "Judicial Appointments" (December 2010) https://www.sabar.co.za/lawjournals/2010/december/2010-december-vol023-no3-pp43-48.pdf (accessed 2019-12-22) 43 and Malan 2014 PER/PELJ 1972-1973. 
Through the above criteria, judges are selected and appointed with the professional responsibility of maintaining the judicial standard of impartiality when presiding over a case. ${ }^{29}$ In $S v$ Le Grange the court confirms:

"It must never be forgotten that an impartial judge is a fundamental prerequisite for a fair trial. The integrity of the justice system is anchored in the impartiality of the judiciary. As a matter of policy, it is important that the public should have confidence in the courts. Upon this social order and security depend. Fairness and impartiality must be both subjectively present and objectively demonstrated to the informed and reasonable observer. ${ }^{30}$

This means that the interest of judges and magistrates should not be focused on a particular outcome or judgment but rather on the interpretation of the law and careful deliberation on the facts, evidence and arguments presented by the prosecution and the defence. ${ }^{31}$ In other words, the expectation is that judges would not develop "a condition or state of mind which sways judgement and renders a judicial officer unable to exercise his or her functions impartially in a particular case". ${ }^{32}$ Also, judges must act as gatekeepers, screening relevant information to ensure that the evidence adduced by the prosecution and the defence are well-founded. ${ }^{33}$

Despite the critical role of judges as impartial arbiters, the findings of recent research studies on cognitive psychology, reveal the problem of unconscious influences on human thought processes, which could undermine fair reasoning. ${ }^{34}$ The next section of this article discusses some manifestations of heuristics and their influence on judicial decision-makers.

\section{HEURISTICS AND COGNITIVE BIAS IN JUDICIAL DECISION-MAKING}

Ideally, the judicial decision-making process would involve a careful weighing-up of all relevant information and evidence. But with the limitation of human cognitive capacity in dealing with vast amounts of information (some of which are ambiguous), there can be situations of unconscious

29 Irwin and Real 2016 McGeorge L Rev 10; Gravett 2017 The South African Law Journal 59 and S v Le Grange supra par 14. Beecher-Monas 2003 L Rev MSU-DCL 989-991.

30 S v Le Grange supra par 21. See also Bernert v Absa Bank Ltd 2011 (3) SA 92 (CC) par 31; Dube $v$ The State (523/07) [2009] ZASCA 28; 2009 (2) SACR 99 (SCA); Sepheka v Du Point Pioneer (J267/18) [2018] ZALCJHB 336; (2019) 40 ILJ 613 (LC) (9 October 2018); S v Roberts 1999 (2) SACR 243 (SCA) par 26.

$31 S v$ Le Grange supra par 21. See also Bernert v Absa Bank Ltd supra par 31; Dube $v$ The State supra 28; Sepheka v Du Point Pioneer supra 336; S v Roberts supra par 26. See also Gravett 2017 The South African Law Journal 75; Irwin and Real 2016 McGeorge L Rev 10 and Beecher-Monas 2003 L Rev MSU-DCL 989-991.

$32 S$ v Le Grange supra par 21. See also Bernert v Absa Bank Ltd supra par 31; Dube $v$ The State supra 28; Sepheka v Du Point Pioneer supra 336; S v Roberts supra par 26.

33 Beecher-Monas 2003 L Rev MSU-DCL 989-991; Daubert v Merrell Dow Pharmaceuticals, Inc 509 U.S. 579 (1993) and Kumho Tire Co. v. Carmichael 526, U.S. 137 (1999).

34 Stafford et al https://pdfs.semanticscholar.org/168e/e8355eced41066c11a195092992da37 c0176.pdf?_ga=2.120098568.1063625548.1576768096-245500049.1568038155 1-3. 
reliance on heuristics. ${ }^{35}$ Heuristics is often in the form of a feeling or impression to ease the burden or complexity of daily decision-making. ${ }^{36}$

As stated in the introduction, reliance on heuristics can speed up a decision-making process and help produce good judgements or create a solution(s) to problems. ${ }^{37}$ But in situations involving judgemental uncertainty, heuristics can produce systematic errors in judgment. ${ }^{38}$ In the words of Reese, "the misapplication of heuristics leads to cognitive biases that prevent people from making the most rational decisions." 39 Below seven different manifestations of heuristics ${ }^{40}$ are briefly discussed:

- Availability heuristic also referred to as judgmental heuristic, occurs when people estimate the frequency or the probability of the occurrence of an event when making a decision. ${ }^{41}$ This estimation is based on how easy it is to recall from memory instances of an event. ${ }^{42}$ If people can recall many instances or examples of an event then there is a possibility of a regular occurrence of the event. ${ }^{43}$ Tversky and Kahneman illustrated the occurrence of availability heuristics through the random sampling of a word of three letters or more from an English text. ${ }^{44}$ The sampling sought to establish whether it is "more likely that the word starts with $r$ or that $r$ is the third letter?"45 The participants recalled words that begin with $r$ (road) and have $r$ in third position (car) and assessed the frequency of the letter by the ease with which the words come to mind. 46

Research studies have shown how availability heuristics can influence a judge's cognitive reasoning in court proceedings. ${ }^{47}$ Saks and Kidd explain:

"The availability heuristic raises important concerns for the presentation of certain kinds of evidence to a fact finder. The subjective estimates of the likelihood that a particular event did occur or that particular consequences

35 Gravett 2017 The South African Law Journal 54; Peer and Gamliel 2013 Court Review 114 and Greene and Ellis https://www.researchgate.net/publication/229737159_Decision_ Making_in_Criminal_Justice 1-2.

36 Gravett 2017 The South African Law Journal 54-55 and Peer and Gamliel 2013 Court Review 114.

37 Ibid.

38 Gravett 2017 The South African Law Journal 55; Reese 2012 UCLA L. REV. 1260 and Sharp 1995 Bulletin of the Australian Society of Legal Philosophy 86.

39 Reese 2012 UCLA L. REV. 1260.

40 See Tversky and Kahneman 1974 Science 1124-185. Reese 2012 UCLA L. REV. 1260 (the author notes that "Cognitive bias comes in many forms, and their classifications are not mutually exclusive."); Guthrie et al 2001 Cornell Law Faculty Publications Paper 780 and Peer and Gamliel 2013 Court Review 114.

41 Tversky and Kahneman 1974 Science 1127 and Greene and Ellis https://www.researchgate.net/publication/229737159_Decision_Making_in_Criminal_Justice 7-10.

42 Peer and Gamliel 2013 Court Review 114; Tversky and Kahneman 1974 Science 1127.

43 Greene and Ellis https://www.researchgate.net/publication/229737159_Decision_Making_in Criminal Justice 8.

44 Tversky and Kahneman 1974 Science 1127.

45 Ibid.

46 Ibid.

47 Saks and Kidd "Human Information Processing and Adjudication: Trial by Heuristics" 1980 1981 Law and Society Review 123137. 
would follow from certain actions will be influenced not only by the actual frequencies of those events but by their availability in memory. Expert witnesses reporting scientific and/or statistical data are likely to have less impact on a fact-finder than does a person who reports a case study, relates a compelling personal experience or offers anecdotal evidence." ${ }^{8}$

This means that evidence that is based on subjective interpretation rather than on objective, scientific or statistical data, may seem more probable to the fact-finder. ${ }^{49}$ Also, when evidence is "more concrete, vivid, emotionrousing and otherwise more salient [it] will be more accessible when a factfinder ponders the decision to be made". ${ }^{50}$ For instance, the manner in which a lawyer presents his or her arguments or an expert witness's anecdotal evidence may affect the way judges think during the decision making process. ${ }^{51}$

In Mashpee Wampanoag Indians $v$ Assessors, the court deliberated on whether or not the plaintiffs who are native Americans, indeed constituted a tribe. ${ }^{52}$ The plaintiff's expert witness, an anthropologist, had anecdotal observational evidence while the defence's expert witness, a sociologist had computer-analysed survey data. ${ }^{53}$ The plaintiff brought a motion to the judge to exclude the sociologist's quantitative evidence because it is "flawed by methodological and analytic errors ..."54 The motion was brought to court probably because of fear that the quantitative evidence may have an overpowering effect. ${ }^{55}$ Saks and Kidd believe the motion was a mistake. ${ }^{56}$ They note:

"First, based on what we know about the availability heuristic, we would predict that the quantitative data of the sociologist would have been less persuasive than the anthropologist's anecdotal report, because the latter would generally be more concrete and salient, and therefore more accessible. Second, and somewhat beside the present point, if the data were flawed, then exposing it to adversary cross-examination would lead the jurors to give it even less weight than their own cognitive processing would normally have given it. ${ }^{57}$

Though the plaintiff won the motion to exclude the sociologist's data, the defence won the case with limited evidence (anecdotal personal observations) presented to the court. ${ }^{58}$

From the case above, the exclusion of the quantitative evidence triggered reliance on limited information which might have affected the judge's intuitive probability estimates. ${ }^{59}$ Also, cross-examination is an important strategy

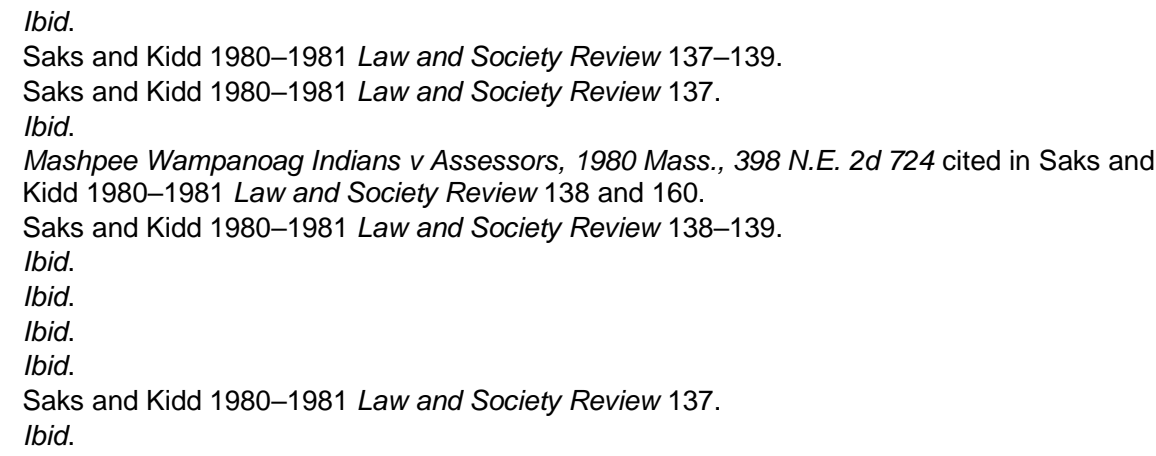


which could have been used to challenge the disputed evidence and discover the truth in the case. ${ }^{60}$ Therefore, cross-examination as a possible strategy to reduce the influence of heuristics in judicial decision-making is considered in Part IV of this article.

- Confirmation bias is the tendency to test a pre-existing belief, expectation or hypothesis by looking for information or evidence that confirms it rather than to consider contrary information or interpretation. ${ }^{61}$ This form of bias "results from a heuristic-based expectation - the natural tendency of human beings to see what they expect to see". 62 In other words, once there is a hypothesis, a decisionmaker develops a (1) biased search for evidence to confirm it or (2) provides a biased interpretation of information ${ }^{63}$ because he or she is convinced about the truth of the hypothesis and would not consider alternative information that proves otherwise. ${ }^{64}$

Several research studies have shown the influence of confirmation bias in criminal proceedings, especially with regard to how it affects judges at the hearing process. ${ }^{65}$ Judges hear and evaluate the evidence presented before the court by forensic experts, police officers/investigators and lawyers etc ${ }^{66}$ but they can be biased and selectively confirm their pre-existing beliefs on the guilt of the accused without considering contrary evidence that may challenge their findings and seek to exonerate the accused. ${ }^{67}$ Also, pretrial detention hearing (or bail hearing) in criminal trials has been identified as possible triggers of confirmation bias in judges. ${ }^{68} \mathrm{~A}$ judge may be influenced

60 Saks and Kidd 1980-1981 Law and Society Review 137. See also Thompson and Scurich "How Cross-Examination on Subjectivity and Bias Affects Jurors' Evaluations of Forensic Science Evidence" 2019 Journal of Forensic Science 1 and Schwikkard and Van der Merwe Principles of Evidence 4ed (2016) 12.

61 PCAST 2016 report 31; see also Rassin et al $2010 \mathrm{~J}$. Investig. Psych. Offender Profil 231232 and Reese 2012 UCLA L. REV. 1260.

62 Reese 2012 UCLA L. REV. 1260.

63 Shiyuan "Cognitive Biases that Lead to Wrongful Convictions: Illustrated by Twenty-Three Erroneous Chinese Cases" 20184 California Western Law Review 4-5; Gravett 2017 The South African Law Journal 69-70 and Ask and Granhag "Motivational Sources of Confirmation Bias in Criminal Investigations: The Need for Cognitive Closure" 2005 Journal of Investigative Psychology and Offender Profiling 43 45. The authors note "The confirmation bias can thus be said to operate by means of two mechanisms - selective information search and biased interpretation of available information." See also Findley and Scott "The Multiple Dimensions of Tunnel Vision in Criminal Cases" 2006 Wisconsin Law Review 292-293.

64 Gravett 2017 The South African Law Journal 69-70.

65 See, for eg., Rassin et al 2010 J. Investig. Psych. Offender Profil 231-232; Reese 2012 UCLA L. REV. 1260; Peer and Gamliel 2013 Court Review 114 and Findley and Scott 2006 Wisconsin Law Review 291-397.

66 See, for eg., Rassin et al 2010 J. Investig. Psych. Offender Profil 232-238; Lidén, Grans and Juslin ''Guilty, No Doubt': Detention Provoking Confirmation Bias in Judges' Guilt Assessments and Debiasing Techniques" 2018 Psychology, Crime and Law 1, 2.

67 Gravett 2017 The South African Law Journal 69-70; Lidén et al 2018 Psychology, Crime and Law 2; Ask and Granhag 2005 Journal of Investigative Psychology and Offender Profiling 45 and Shiyuan 2018 California Western Law Review 4-5.

68 Lidén et al 2018 Psychology, Crime and Law 2 and 19-20. The findings of the studies conducted by the authors showed that judges' detention of suspects can trigger a confirmation bias and significantly increase the probability of the suspect's guilt and a conviction. Also, the authors note that "the results illustrate an interaction between the detention decision and the decision-maker, meaning that participants made more guilt 
by the information on a case or about a suspect and hypothesise or conclude on the probability of the guilt of an accused person. ${ }^{69}$

The influence of confirmation bias is recognised as a contributing factor to the wrongful conviction in the Schiedam Park murder case, in the Netherlands, where a ten-year-old girl was murdered and her friend assaulted. ${ }^{70}$ The latter survived the attack. Kees Borsboom was identified as a witness in the murder case after the surviving child met him cycling in the park and asked him to call the police. ${ }^{71}$ However, Borsboom became a prime suspect in the same murder case when it was found by the police that he had solicited sexual acts from a minor (a boy) at the same park weeks before the murder of the girl. ${ }^{72}$ Borsboom initially confessed to the murder but later argued that it was made under duress. In fact, the surviving child's description of the perpetrator of the crime did not fit Borsboom's appearance, neither did the description of events leading to the murder match details provided in Borsboom's confession. ${ }^{73}$ Also, the DNA evidence obtained from the crime scene was not a match with Borsboom. ${ }^{74} \mathrm{He}$ was convicted and sentenced to prison but released four years later following the confession by the real perpetrator of the crime and a positive DNA match. ${ }^{75}$ An investigation into this case revealed that tunnel vision, also referred to as confirmation bias, influenced the judgment and the miscarriage of justice. ${ }^{76}$ It seems that the police, public prosecution and the judge were convinced by the incriminating evidence which pointed to the guilt of Borsboom and overlooked the exonerating evidence that he was not guilty. ${ }^{77}$

- Egocentric bias occurs when people make judgements about themselves and their abilities in an egocentric or self-serving way. ${ }^{78}$

People are influenced by different self-serving factors that define how they make their decisions about themselves in terms of whether they

presumptive ratings of the suspect's trustworthiness, the guilt consistent evidence as well as the total evidence and were also more likely to convict if they themselves had previously detained the suspect."

69 Lidén et al 2018 Psychology, Crime and Law 2 and 19-20.

70 Van Koppen "Blundering Justice: The Schiedam Park Murder" in Kocsis (ed) Serial Murder and the Psychology of Violent Crimes (2008) 207-216 and Rassin et al $2010 \mathrm{~J}$. Investig. Psych. Offender Profil 233 and Van Koppen "Finding False Confessions" in Bull, Valentine and Williamson (eds) Handbook of Psychology of Investigative Interviewing: Current Developments and Future Directions (2009) 62-64.

71 Van Koppen in Kocsis Serial Murder and the Psychology of Violent Crimes 207-216.

72 Van Koppen in Kocsis Serial Murder and the Psychology of Violent Crimes 208.

73 Van Koppen in Bull et al Handbook of Psychology of Investigative Interviewing: Current Developments and Future Directions 62-64.

74 According to Van Koppen, the DNA was found under the nails and on the rubber boot of the girl and the surviving child belonged to someone other than the children, an unknown male person. See Van Koppen in Kocsis Serial Murder and the Psychology of Violent Crimes 213.

75 Rassin et al 2010 J. Investig. Psych. Offender Profil 233 and Van Koppen in Kocsis Serial Murder and the Psychology of Violent Crimes 210-213.

76 Rassin et al $2010 \mathrm{~J}$. Investig. Psych. Offender Profil 232-233.

77 Van Koppen in Kocsis Serial Murder and the Psychology of Violent Crimes 207-216.

78 Guthrie et al 2001 Cornell Law Faculty Publications Paper 811-812 and Beecher-Monas 2003 L Rev MSU-DCL 1006-1008. 
are better than average or when to overestimate their abilities. ${ }^{79}$ Research studies have revealed the likelihood of judges being susceptible to egocentric biases which make them believe they are better decision-makers. ${ }^{80}$ For example, the study by Guthrie, Rachlinski and Wistrich demonstrated the influence of egocentric bias in judges. ${ }^{81}$ About 155 judges who participated in the study were asked anonymously to estimate the reversal rate of their decisions on appeal. ${ }^{82}$ Also, the judges were asked, "to place themselves into the quartile corresponding to their respective reversal rates: highest (i.e., $>75 \%$ ), second-highest $(>50 \%)$, third-highest $(>25 \%)$, or lowest $(<25 \%) " .83$ The result showed that $56.1 \%$ of the judges placed themselves in the lowest quartile; $31.6 \%$ were in the second-lowest quartile; $7.7 \%$ in the secondhighest quartile, and $4.5 \%$ in the highest quartile. ${ }^{84}$ In other words, about $87.7 \%$ of the judges believed their colleagues have a higher reversal rate on appeal when compared to them. ${ }^{85}$ This study reveals the strong influence of egocentric bias in the judges which prevented them from placing themselves in the high reversal rate on appeal. ${ }^{86}$ The judges believed that they made better decisions. ${ }^{87}$ This implies that when judges rely on the self-serving or egocentric bias, they become overconfident which precludes them from acknowledging any mistakes or limitations relating to their decisions. ${ }^{88}$

- Anchoring occurs when people make estimates or decisions based on a standard of reference (also referred to as initial value, starting point or a numeric reference point) or what is called an anchor. ${ }^{89}$ The anchor influences what decision-makers will consider as the final value or numeric estimates/judgments based on adjustments made from or towards the anchor. ${ }^{90}$ The anchor induces decision-makers "to consider

79 Guthrie et al 2001 Cornell Law Faculty Publications Paper 811-812 and Babcock and Loewenstein "Explaining Bargaining Impasse: The Role of Self-Serving Biases" 199711 Journal of Economic Perspectives 109-126 and Greene and Ellis https://www.researchgate.net/publication/229737159_Decision_Making_in_Criminal_Justice 21.

80 See, for eg., Guthrie et al 2001 Cornell Law Faculty Publications Paper 811-812 and Greene and Ellis https://www.researchgate.net/publication/229737159_Decision_Making_in Criminal_Justice 21.

81 Guthrie et al 2001 Cornell Law Faculty Publications Paper 813-814.

82 Ibid.

33 Ibid.

34 Ibid.

85 Guthrie et al 2001 Cornell Law Faculty Publications Paper 813-814; see also Greene and Ellis https://www.researchgate.net/publication/229737159_Decision_Making_in_Criminal_ Justice 22-23.

86 Greene and Ellis https://www.researchgate.net/publication/229737159_Decision_Making_ in_Criminal_Justice 22-2 and Guthrie et al 2001 Cornell Law Faculty Publications Paper 813-814.

87 Greene and Ellis https://www.researchgate.net/publication/229737159_Decision_Making_in Criminal_Justice 22-23.

88 Guthrie et al 2001 Cornell Law Faculty Publications Paper 815.

89 Tversky and Kahneman 1974 Science 1128 and Guthrie et al 2001 Cornell Law Faculty Publications Paper 787-788; Rachlinski et al 2015 Indiana Law Journal 695 and Hollier https://www.thelawproject.com.au/insights/anchoring-bias-in-the-courtroom.

90 Tversky and Kahneman 1974 Science 1128-1129 and Guthrie et al 2001 Cornell Law Faculty Publications Paper 787-788. 
seriously the possibility that the numeric estimates are similar to the anchor, thereby leading them to envision circumstances under which the anchor would be correct". ${ }^{91}$ The reliance on an anchor may provide relevant information about the estimates ${ }^{92}$ but, in some situations, the anchor may provide no relevant information and still influence the adjustments made to the numeric estimates ${ }^{93}$ because it is often difficult to ignore a previously considered standard. ${ }^{94}$

Research studies have shown how anchors influence decision-makers in different situations..$^{95}$ Anchors often influence decisions made by judges, especially in civil compensatory damages awards ${ }^{96}$ and criminal sentencing (i.e., prison sentence or fine).$^{97}$ Englich, Mussweiler and Strack noted that it seems highly unlikely that a judicial decision with far-ranging implications can be influenced by a standard of reference or an anchor. ${ }^{98}$ This is because judges are well trained and have lots of professional experience to handle the different issues that arise in criminal cases. ${ }^{99}$ Furthermore, judges are well-guided by relevant procedural rules of law and sentencing guidelines. ${ }^{100}$

91 Guthrie et al 2001 Cornell Law Faculty Publications Paper 788.

92 Ibid.

93 Ibid.

94 Guthrie et al 2001 Cornell Law Faculty Publications Paper 788 and Englich and Mussweiler "Sentencing Under Uncertainty: Anchoring Effects in the Courtroom" 200131 Journal of Applied Social Psychology 1536

95 See, for eg., Tversky and Kahneman's well-cited illustration of anchoring, where participants were asked to indicate whether the percentage number of African countries in the United States is higher or lower than a standard or anchor determined by the spinning of a wheel of fortune. The participants were grouped with one group arriving at $10 \%$ and the other group $65 \%$ after spinning. The determined anchors influenced the participants' estimates, with the first group with the low anchor arriving at $25 \%$ and the other group with high anchor arriving at $45 \%$. Also, a study where students were to determine whether the average cost of a college textbook was higher or lower than $\$ 7128.53$ (the anchor). The result showed that students thought the textbooks were higher than they believed it to be. Tversky and Kahneman 1974 Science 1128; Guthrie et al 2001 Cornell Law Faculty Publications Paper 788 and Rachlinski et al 2015 Indiana Law Journal 701-702.

96 See, for eg., Guthrie et al 2001 Cornell Law Faculty Publications Paper 790-791 and Rachlinski et al 2015 Indiana Law Journal 707. In the study conducted 106 federal magistrate judges were presented with a hypothetical personal injury lawsuit. The plaintiff in the case was seriously injured in an accident involving the defendant's truck. Police investigation revealed that the truck had faulty braking system and the truck was not properly maintained. The plaintiff requested for the court to award damages for lost wages (he was unable to walk and work), hospital bills and pain/suffering, but he did not specify an amount for the damages. The judges were grouped into two: Group one has no anchor condition and asked to specify an amount to award the plaintiff as compensatory damages. In group two the judges were asked to make similar award but provided with an anchor condition that "the defendant has moved for dismissal of the case, arguing that it does not meet the jurisdictional minimum for a diversity case of $\$ 75,000$." The $\$ 75,000$ served as the anchor. The judges in group two were asked to make a ruling on the motion and specify an amount to award the plaintiff if the motion was denied. The result showed that the judges that did not receive the anchor awarded the plaintiff $\$ 1,249,000$ while the judges with the anchor condition $\$ 75,000$ awarded the plaintiff $\$ 882,000$.

97 Rachlinski et al 2015 Indiana Law Journal 695 and 706 and Englich and Mussweiler 2001 Journal of Applied Social Psychology 1537.

98 Englich, Mussweiler and Strack "Playing Dice with Criminal Sentences: The Influence of Irrelevant Anchors on Exerts Judicial Decision Making" 2006 Personality and Social Psychology Bulletin 189.

99 lbid.

100 Ibid. 
However, research findings have revealed that judicial decisions can be influenced by anchors under certain conditions, irrespective of professional training and experience. ${ }^{101}$

For example, Englich and Mussweiler demonstrated in a hypothetical case of an alleged rape that "sentencing demands can serve as anchors to which a final sentence is assimilated" despite other potential influences like the severity of the crime or the accused's criminal record etc. ${ }^{102}$ Nineteen German trial judges participated in the study and were handed all appropriate case materials. ${ }^{103}$ About half of the participants were told the prosecutor demanded a sentence of 34 months for the accused person and the other half were informed that he demanded a sentence of 2 months. ${ }^{104}$ The result showed that "the given sentences were higher for participants who evaluated the high sentencing demand $(m=28.70$, SD 6.53) than for participants who evaluated the low sentencing demand (m 18.78 months, $\mathrm{SD}=9.11)$ ". 105

One of the studies conducted by Englich, Mussweiler and Strack showed that irrelevant anchors can influence criminal sentencing. ${ }^{106}$ They examined "whether a sentencing anchor that is suggested by the media may influence judges' sentencing decisions". 107 The experiment involved the participation of 43 experienced legal practitioners (23 judges and 19 prosecutors) $)^{108}$ at educational conferences for judges and prosecutors. The judges/participants received materials with realistic relevant information on an alleged rape case and were asked to take on the role of the criminal judge in this case. ${ }^{109}$ During the court recess, a media reporter called the judges and asked the question: "Do you think that the sentence for the defendant in this case will be higher or lower than 1 or 3 year(s)?"110 About half of the judges thought the prison sentence for the defendant in this case will be high and the other half decided on the low prison sentence. ${ }^{111}$ Media scrutiny which is irrelevant to a judicial decision, should normally not influence a court's sentencing, but the results of this experiment have shown that judges can be influenced by irrelevant sentencing anchors. ${ }^{112}$

101 Englich et al 2006 Personality and Social Psychology Bulletin 189; see also Guthrie et al 2001 Cornell Law Faculty Publications Paper 788 and Rachlinski et al 2015 Indiana Law Journal 703.

102 Englich and Mussweiler 2001 Journal of Applied Social Psychology 1535-1538 and Rachlinski et al 2015 Indiana Law Journal 695 and 706.

103 Englich and Mussweiler 2001 Journal of Applied Social Psychology 1535-1538.

104 Ibid.

105 Ibid.

106 Englich et al 2006 Personality and Social Psychology Bulletin 190.

107 Ibid.

108 The legal education system in Germany allows judges and prosecutors to receive the same legal training as well as alternate between their positions in the first years of their professional training and practice. Englich et al 2006 Personality and Social Psychology Bulletin 190-191.

109 lbid.

110 lbid.

111 Ibid.

112 Englich et al 2006 Personality and Social Psychology Bulletin 192; Fitzmaurice and Pease The Psychology of Judicial Sentencing (1986). 
- Hindsight bias: Generally, before events occur, they are less predictable. ${ }^{113}$ But when they occur and are evaluated, there is the tendency for people exposed to the events to exhibit hindsight bias (also known as "we knew it all along" phenomenon). ${ }^{114}$ This means people overestimate the predictability of past events or assign higher probabilities to the outcome of events that have occurred as though they knew it all along or could have foreseen it. ${ }^{115}$ Harley, Carlsen and Loftus note that "Hindsight bias is thought to result from cognitive reconstruction processes that occur after outcome information is received." 116

Several studies have shown that hindsight bias has affected court judgments, specifically, related to negligence, liability and medical practice. ${ }^{117}$ For instance, many medical malpractice litigations in radiology involving diagnostic, perceptual, or decision-making errors have been linked with hindsight bias. ${ }^{118}$ In court cases like this, "the task of the judge is to assess how foreseeable an outcome was and to evaluate whether the plaintiff's behaviour took this risk into consideration." 119 But the problem in these types of court cases is that judges evaluate outcomes after the fact and in hindsight, while the plaintiff only had the chance to provide foresight about it. ${ }^{120}$

Peer and Gamliel illustrated in their study the effect of hindsight bias in a malpractice claim case where the physician was accused of malpractice because of his failure to detect a tiny tumour in early chest radiography. ${ }^{121}$ The tumour got bigger and the patient died. The court found the physician guilty after a second radiologist who saw the radiographs after the tumour was found, testified that the tumour could have been detected in the early chest radiography. ${ }^{122}$ The second radiologist's evaluation in hindsight was an advantage the first physician did not have at the time. ${ }^{123}$

Similarly, in Gehlen v Snohomish Public Hospital (a medical malpractice case) the plaintiff's expert evaluated the radiograph and testified (in

113 Peer and Gamliel 2013 Court Review 115.

114 Peer and Gamliel 2013 Court Review 115; see also Rachlinski 2000 Oregon Law Review 66-80 and Guthrie et al 2001 Cornell Law Faculty Publications Paper 799-701.

115 Ibid.

116 Harley, Carlsen and Loftus "The Saw It All Along Effect: Demonstrations of Visual Hindsight Bias" 200430 Journal of Experimental Psychology: Learning, Memory and Cognition 960.

117 See, for eg., Roese "I Knew it all Along ... Didn't I? Understanding Hindsight Bias" (6 September 2012) Psychological Science https://www.psychologicalscience.org/news/ releases/i-knew-it-all-along-didnt-i-understanding-hindsight-bias.html (accessed 2019-0726); Peer and Gamliel 2013 Court Review 115 and 118; Rachlinski 2000 Oregon Law Review 69-70 and Guthrie et al 2001 Cornell Law Faculty Publications Paper 799-701.

118 Harley et al 2004 Journal of Experimental Psychology: Learning, Memory and Cognition 960.

119 Peer and Gamliel 2013 Court Review 115 and 118 and Rachlinski 2000 Oregon Law Review 69.

120 Peer and Gamliel 2013 Court Review 115.

121 Ibid.

122 lbid.

$123 \mathrm{lbid}$ 
hindsight) that the radiologist should have seen the small mass. ${ }^{124}$ The court also deliberated on whether or not the radiologist's failure to see the small mass resulted from "negligence" or "perceptual error". ${ }^{125}$ One of the experts called to testify on perceptual error notes that: "In his opinion, all radiologists make perceptual errors [that is looking at an object or features associated and not seeing it], and it would be impossible for a reasonably prudent radiologist to interpret $x$-rays on a daily basis without making perceptual errors." ${ }^{26}$ The expert also noted that " 80 per cent of cases in which a radiologist makes a significant diagnostic error, the reason for the diagnostic error is a perceptual error."127 But after Gehlen's case, Harley, Carlsen and Loftus illustrated in their study how hindsight bias might apply to visual perception. ${ }^{128}$ They used radiology data as an example to show that "82\% of missed tumors were 'visual in hindsight' by radiologists with outcome knowledge."129 This study confirms the susceptibility of radiologists who are expert witnesses to hindsight bias, the potential for error and its profound impact on the quality of decision-making.

- Framing can occur when a person is confronted with making "risky or uncertain decisions - such as deciding whether to settle a case or to proceed to trial - they tend to categorise their decision options as potential gains or losses from the status quo". ${ }^{130}$ The categorisation, also referred to as "framing" of decision options, influences a person's evaluation and the extent to which he or she is willing to incur risk. ${ }^{131}$ Guthrie, Rachlinski and Wistrich explain further on the concept of framing:

"People tend to make risk-averse decisions when choosing between options that appear to represent gains and risk-seeking decisions when choosing between options that appear to represent losses. For example, most people prefer a certain $\$ 100$ gain to a $50 \%$ chance of winning $\$ 200$ but prefer a $50 \%$ chance of losing $\$ 200$ to a certain $\$ 100$ loss."

124 See Gehlen v Snohomish County Public Hospital District No. 1, 2001 WL 815005 (Wash.App.Div. 1) (unpublished opinion) cited in Johns "What Was He Thinking? Beyond Bias - To Decision Making and Judging" (8 March 2007) https://gacc.nifc.gov/swcc/dispatch 125 lbid. logistics/overhead/imt/documents/what was he thinking.pdf (accessed 2020-01-05) 8.

126 Ibid.

127 Ibid.

128 See Harley et al 2004 Journal of Experimental Psychology: Learning, Memory and Cognition 960-968.

129 The empirical data was taken from Muhm, Miller, Fontana, Sanderson and Uhlenhopp "Lung Cancer Detected During a Screening Program Using Four-Month Chest Radiographs" Radiology 609-615. The authors conducted a screening program at the Mayo Clinic for men at high risk of lung cancer. The study involved 4,618 members whose chest radiographs were obtained every 4 months, "and each radiograph was read by two to three radiologists or chest physicians". Over the course of the 6-year study, 92 tumors were detected in the study group. Of these, $75(82 \%)$ were, as the authors termed it, "visible in retrospect". See Harley et al 2004 Journal of Experimental Psychology: Learning, Memory and Cognition 961 and Johns https://gacc.nifc.gov/swcc/dispatch_logistics/overhead/imt/ documents/what_was_he_thinking.pdf 9.

130 Guthrie et al 2002 Judicature 46.

131 Guthrie et al 2002 Judicature 46; see also Guthrie et al 2001 Cornell Law Faculty Publications Paper 794. 
Research studies have shown that framing can have profound effect on civil law cases. ${ }^{132}$ In such cases, plaintiffs are confronted with decision options of "either to accept a certain settlement from the defendant or to gamble, hoping that further litigation will produce a larger gain". ${ }^{133}$ For defendants, the decision options are "either to pay a certain settlement to the plaintiff or to gamble that further litigation will reduce the amount that they must pay." 134 Thus, from the plaintiffs' perspective the chosen option seems to represent gains ("settlement, the risk-averse option") while the defendants' options seem to represent losses ("trial, risk-seeking option"). ${ }^{135}$

Judges play a critical role in settlement talks between plaintiffs and defendants, but framing can influence them when making decisions. ${ }^{136}$ The study conducted by Guthrie, Rachlinski and Wistrich have revealed that "framing can detrimentally impact judicial management of law suits." 137 In this study, some judges were asked to preside over a case labelled "suit and settlement" in which a plaintiff sued the defendant for $\$ 200,000$ in a copyright action. ${ }^{138}$ The plaintiff and defendant are publishing companies. The dispute focused on "whether the defendant's actions infringed on the plaintiff's copyright." 139 It is also stated in the case study that the judges must believe that "the plaintiff has a $50 \%$ chance of recovering the full $\$ 200,000$ and a $50 \%$ chance of recovering $\$ 0 . " 140$ Also, the judges must note that "should the parties fail to settle each will spend approximately $\$ 50,000$ at trial in litigation expenses. Assume that there is no chance that the losing party will have to compensate the winner for these expenses." 141

Half of the judges view this case from the plaintiff's perspective in which the choice involved potential gains. The judges learnt that the defendant intends to offer $\$ 60,000$ to the plaintiff to settle the case and were asked the question: "Do you believe that the plaintiff should be willing to accept $\$ 60,000$ to settle the case?"142 The judges response should be a "Yes or No" answer. In this instance, the plaintiff is confronted with "a choice between a certain $\$ 60,000$ gain or an expected trial outcome of $\$ 50,000$." 143

The other half of the judges represent the defendant's perspective in which the choice involved potential losses. ${ }^{144}$ The judges also learnt that the plaintiff's intended to accept $\$ 140,000$ from the defendant to settle the case

132 See Guthrie et al 2002 Judicature 46-47 and Guthrie et al 2001 Cornell Law Faculty Publications Paper 794-799.

133 Guthrie et al 2001 Cornell Law Faculty Publications Paper 795 and Guthrie et al 2002 Judicature 46

134 Ibid.

135 Guthrie et al 2001 Cornell Law Faculty Publications Paper 798

136 Guthrie et al 2002 Judicature 46 and Guthrie et al 2001 Cornell Law Faculty Publications Paper 798.

137 Ibid.

138 Guthrie et al 2001 Cornell Law Faculty Publications Paper 796.

139 Ibid.

140 lbid.

141 Ibid.

142 Guthrie et al 2001 Cornell Law Faculty Publications Paper 796-797.

143 Guthrie et al 2001 Cornell Law Faculty Publications Paper 796-797; see Guthrie et al 2002 Judicature 46-47.

144 Guthrie et al 2001 Cornell Law Faculty Publications Paper 797. 
and were asked "Do you believe that the defendant should be willing to pay $\$ 140,000$ to settle the case?"145 The judges response should also be a "Yes or No" answer. In this instance, the defendant is confronted with "a choice between a certain $\$ 140,000$ loss or an expected trial outcome of $\$ 150,000 " .{ }^{146}$ The results revealed:

"Among the judges evaluating the case from the plaintiff's perspective, $39.8 \%$ (thirty-three out of eighty-three) indicated that they thought the plaintiff should accept the $\$ 60,000$ settlement offer, but only $25 \%$ (twenty out of eighty) of the judges evaluating the case from the defendant's perspective indicated that they thought the defendant should pay the $\$ 140,000$ settlement payment proposed by plaintiff." 147

Thus, the judges were more inclined towards the plaintiff accepting a settlement. The framing of decision problems seem to influence how judges perceive settlement decisions. ${ }^{148}$

- The representativeness heuristic can occur when people assess the probability of certain events (or behaviour) and rely on apparent similarities between the features of the events and the features of a particular category, in order to determine whether the events are representative of the category. ${ }^{149}$ Guthrie, Rachlinski and Wistrich explain:

"When people make categorical judgments (e.g., assessing the likelihood that a criminal defendant is guilty), they tend to base their judgments on the extent to which the evidence being analysed (e.g., the defendant's demeanour) is representative of the category. When the evidence appears representative of, or similar to, the category (e.g., the defendant is nervous and shifty), people judge the likelihood that the evidence is a product of that category as high (i.e., evidence of guilt). When the evidence being analysed does not resemble the category (e.g., the defendant appears at ease), people judge the likelihood that the evidence is a product of that category as low (i.e., evidence of innocence)."150

This is a case of reliance on similarity likelihood rather than on statistical likelihood. ${ }^{151}$ The judge's ability to observe and draw inferences from the demeanour, that is the visible or audible expression, ${ }^{152}$ of witnesses,

145 Guthrie et al 2001 Cornell Law Faculty Publications Paper 797; see Guthrie et al 2002 Judicature 46-47.

146 lbid.

147 lbid.

148 lbid.

149 Rachlinski 2000 Oregon Law Review 82; Guthrie et al 2001 Cornell Law Faculty Publications Paper 805-806 and Greene and Ellis https://www.researchgate.net/publication/ 229737159 Decision Making in Criminal Justice 11-12.

150 Guthrie et al 2001 Cornell Law Faculty Publications Paper 805.

151 Johns https://gacc.nifc.gov/swcc/dispatch_logistics/overhead/imt/documents/what_was_he_ thinking.pdf 11 .

152 These include 'witnesses' manner of testifying, character, personality and the impression they create. Whether they are candid or evasive, ready or reluctant in giving their version, whether they hesitate unnecessarily, fidget nervously, twitch facially in response to straight forward questions, and 'a thousand other considerations' cumulatively contribute to shaping demeanour". See $S$ v Shaw [2011] ZAKZPHC 32 AR342/10 78; Schwikkard and Van de Merwe Principles of Evidence 575 and Naude "Face-Coverings, Demeanour Evidence and the Right to a Fair Trial: Lessons From the USA and Canada" 201346 The Comparative and International Journal of Southern Africa 168. 
contributes to confirming the probative value of the testimony presented in court. ${ }^{153}$ Demeanour of witnesses is considered real evidence as the court is observing an evidentiary fact. ${ }^{154}$ However, this evidence is controversial in nature, in the sense that, it is not enough to confirm the likelihood of the guilt of an accused based on expressions displayed in court or confirm the credibility of an expert's testimony by the manner he or she testifies. ${ }^{155}$ Also, the court's observation of demeanour is subjective with the danger of human error. ${ }^{156}$

The problem with the value of demeanour evidence has been pointed out by the South African courts. ${ }^{157}$ In Medscheme Holdings (Pty) Ltd $v$ Bhamjee ${ }^{158}$ the court stated:

"An assessment of evidence on the basis of demeanour - the application of what has been referred to disparagingly as the 'Pinocchio theory' - without regard for the wider probabilities, constitutes a misdirection. Without a careful evaluation of the evidence that was given (as opposed to the manner in which it was delivered) against the underlying probabilities, which was absent in this case, little weight can be attached to the credibility findings of the court a quo."

Courts have reiterated the need for demeanour evidence to be applied wisely. 159 The following principles have been summed up for consideration when interpreting demeanour evidence. They include:

"(a) Demeanour in itself is a fallible guide to credibility and should be considered with all other factors: it is in the overall scrutiny of evidence that demeanour should be considered and then only if there are sufficient indications thereof to be significant. ${ }^{160}$

(b) The limited value of a finding on demeanour becomes even less where an interpreter is used. ${ }^{161}$

(c) The Constitutional Court has pointed out the danger of assuming that: 'all triers of fact have the ability to interpret correctly the behaviour of a witness, notwithstanding that the witness may be of a different culture,

153 Naude 2013 The Comparative and International Journal of Southern Africa 166-167.

154 Naude 2013 The Comparative and International Journal of Southern Africa 166 and Schwikkard and Van der Merwe Principles of Evidence 575.

155 Naude 2013 The Comparative and International Journal of Southern Africa 167 (the author notes that "it is possible that an honest witness may be shy or nervous by nature while a dishonest and crafty witness may simulate an honest demeanour" and "it would be wrong to assume that those who are lying display behavioural signs of lying, or that those who are telling the truth will not show signs that may create the appearance of lying"). See also Mofutsana v S (A287/2017) [2018] ZAFSHC 170 (1 November 2018) 18-19.

156 Mofutsanav S supra 20.

157 See, for eg., Mofutsana v S supra 20; S v Shaw supra 77-82 and President of the Republic of South Africa v South African Rugby Football Union [1999] ZACC 11; 2000 (1) SA 177 79.

1582005 (5) SA 339 14; see also Mofutsana v S supra 20.

159 lbid.

160 S v Shaw supra 78-80; Mofutsana v S supra 20; Cloete v Birch 1993 (2) PH F17 (E) and S $v$ Civa 1974 (3) SA 844 (T). See also Schwikkard and Van der Merwe Principles of Evidence 575.

161 Mofutsana v S supra 20; S v Malepane 1979 (1) SA 1009 (w) 1016H-1017A; Rex v Dhlumayo 1948 (2) SA 677 (A) 697 and Body Corporate of Dumbarton Oaks v Faiga 1999 (1) SA 975 (SCA). See also Schwikkard and Van der Merwe Principles of Evidence 575. 
class, race or gender and someone whose life experience differs fundamentally from that of the trier of fact. ${ }^{162}$

(d) Demeanour can hardly ever be decisive in determining the outcome of a case. Demeanour is merely one factor to be taken into account: 'In addition to the demeanour of the witness', said Krause $\mathrm{J}$ in $R v$ Momekela \& Commandant ${ }^{163}$ 'one should be guided by the probability of his story, the reasonableness of his conduct, the manner in which he emerges from the test of his memory, the consistency of his statements and the interest he may have in the matter under enquiry.' ${ }^{164}$

(e) A trial court is obviously in a better position than the court of appeal to make a finding on demeanour, and the court of appeal "must attach weight, but not excessive weight" to the trial court's finding. It is as a general rule important that a trial court should record its impression of the demeanour of a material witness." 165

While the South African courts have emphasised caution when applying demeanour evidence, a clear link with representativeness heuristic, which is from the psychology discipline, has not been shown. Research studies on the representativeness heuristic have noted the problem of the misinterpretation of evidence when a judge relies too much on it. ${ }^{166}$ For example, Greene and Ellis note that "child witness demeanour [i.e., crying] in the courtroom can affect perceptions of the child and of the defendant's guilt." 167

Over-reliance on representativeness heuristics can lead judges to "downplay the importance of the probability of a random match" or "disregard other characteristics of the evidence that undermine its probative value, such as the probability of laboratory error or other mismanagement of the evidence". 168

While representativeness heuristic may be useful in decision-making, it can lead decision-makers to discount relevant statistical evidence. ${ }^{169}$ Judges might ignore or discount what is known as base-rate statistics that are considered highly relevant for decisions. ${ }^{170}$ Base-rate statistics is the probability with which a crime or an event actually occurs. ${ }^{171}$ In situations where base-rate statistics are ignored, it can induce a problem known as an

162 President of the Republic of South Africa v South African Rugby Football Union supra 79; See also Mofutsana v S supra 20 and Schwikkard and Van der Merwe Principles of Evidence 575-576.

1631936 OPD 24 and Schwikkard and Van der Merwe Principles of Evidence 576.

164 Mofutsana v S supra 20; Cloete v Birch supra and Schwikkard and Van der Merwe Principles of Evidence 576

165 Mofutsana v S supra 20; S v Mwanyekanga 1993 (2) PH H54 (C); see S v Jochems 1991 (1) SACR 208 (A). See also Schwikkard and Van der Merwe Principles of Evidence 576.

166 See, for eg., Rachlinski 2000 Oregon Law Review 85-86.

167 Greene and Ellis https://www.researchgate.net/publication/229737159_Decision_Making_in _Criminal_Justice 12.

168 Ibid.

169 Johns https://gacc.nifc.gov/swcc/dispatch_logistics/overhead/imt/documents/what_was_he_ thinking.pdf 9 .

170 Johns https://gacc.nifc.gov/swcc/dispatch_logistics/overhead/imt/documents/what_was_he_ thinking.pdf 9 and Guthrie et al 2001 Cornell Law Faculty Publications Paper 806.

171 Greene and Ellis https://www.researchgate.net/publication/229737159_Decision_Making_in Criminal_Justice 12. 
inverse fallacy. ${ }^{172}$ Guthrie, Rachlinski and Wistrich describe inverse fallacy as;

"The tendency to treat the probability of a hypothesis given the evidence (for example, the probability that a defendant was negligent given that a plaintiff was injured) as the same as, or close to, the probability of the evidence given the hypothesis (for example, the probability that the plaintiff would be injured if the defendant was negligent)". .73

Guthrie, Rachlinski and Wistrich examined the possibility that judges would commit the inverse fallacy. ${ }^{174}$ Using a res ipsa loquitur ${ }^{175}$ a problem in a Torts case some judges were given a brief description of a case based on the classic English case Byrne $v$ Boadle. ${ }^{176}$ The plaintiff was struck by a barrel that was being hoisted into the warehouse while passing the defendant's warehouse. ${ }^{177}$ An investigation was conducted by the Government safety inspectors and they determined that "a) when barrels are negligently secured, there is a $90 \%$ chance that they will break loose; (b) when barrels are safely secured, they break loose only $1 \%$ of the time and c) workers negligently secure barrels only 1 in 1,000 times". ${ }^{178}$ Based on the facts provided, the judges were asked: "how likely is it that the barrel fell due to negligence of one of the workers". ${ }^{179}$ The findings showed that the probability that the defendant was negligent is actually only $8.3 \%$, although most people commit the inverse fallacy and assume the likelihood of negligence is as high as $90 \%$ "because they fail to attend to the base rate (that workers negligently secure barrels only 1 time in 1000 attempts)". ${ }^{180}$ About $40 \%$ of judges selected a correct answer in the range $0-25 \%$ (probability of negligence). ${ }^{181}$ The remaining $60 \%$ of judges who did not choose the correct answer, exhibited a tendency to select the highest range which suggested they committed an inverse fallacy. ${ }^{182}$

172 Guthrie et al 2001 Cornell Law Faculty Publications Paper 807.

73 Ibid.

174 Guthrie et al 2001 Cornell Law Faculty Publications Paper 808

175 Res ipsa loquitur is a legal doctrine used "to describe situations where notwithstanding the plaintiff's inability to establish the exact cause of the accident the fact of the accident by itself is sufficient to justify the conclusion that the defendant was probably negligent, and in the absence of an explanation by the defendant to the contrary that such negligence caused the injury to the plaintiff". See Van den Heever and Lawrenson "Inference of Negligence - Is it Time to Jettison the Maxim Res Ipsa Loquitur?" http://www.saflii.org/za/journals/ DEREBUS/2015/15.html (accessed 2020-01-12).

176159 Eng. Rep. 299 (Ex. Ch. 1863) cited Guthrie et al 2001 Cornell Law Faculty Publications Paper 808.

177 Guthrie et al 2001 Cornell Law Faculty Publications Paper 808-809 and Greene and Ellis https://www.researchgate.net/publication/229737159_Decision_Making_in_Criminal_Justice 15-16.

178 lbid.

179 lbid.

180 lbid.

181 lbid.

182 Guthrie et al 2001 Cornell Law Faculty Publications Paper 808-809. 


\section{Coherence-based reasoning}

This article considers coherence-based reasoning because it is recognised as "a general model of judgment and decision-making in conditions of complexity". ${ }^{183}$ Also, it differs from biases and heuristics which deal with more specific situations or evidence and narrowly defined tasks of judgement and choice. ${ }^{184}$ Coherence-based reasoning involves the mental tasks of evaluating pieces of evidence in a legal case to establish the strength of all the evidence as either strong or weak in order to confirm the guilt of the accused. ${ }^{185}$ It is also a theoretical framework for decision-making from a psychological perspective. ${ }^{186}$ This framework "applies whenever people must derive a conclusion on the basis of the integration of numerous ambiguous, complex, and contradictory inferences". 187 Coherence-based reasoning involves "an unconscious transformation of the way decisions are mentally represented, ultimately leading to a seemingly straightforward choice between a compelling alternative and a weak one". ${ }^{188}$

Research studies have shown that coherence-based reasoning applies to the mental process involved in dealing with the complexities in legal cases. ${ }^{189}$ Charman, Douglas and Mook note that the underlying idea behind this theoretical framework as it applies to legal decision-making is that:

"[v]arious propositions (pieces of evidence, beliefs about the suspect, etc.) to be integrated into a final assessment (e.g., a guilty/not guilty verdict) can be represented as a network of nodes that are interconnected via a series of excitatory and inhibitory links that represent positive or negative relationships, respectively, between the nodes. When individuals are making a decision regarding that information (e.g., deciding on the guilt of a suspect), a parallel constraint satisfaction mechanism settles the entire network into a state that maximizes coherence among the elements". ${ }^{190}$

Charman, Douglas and Mook's illustration is based on a detective investigating a case and who has four pieces of evidence concerning an accused person. ${ }^{191}$ The evidence includes: "cell phone records that place the suspect in the vicinity of the crime, an eyewitness identification of the suspect, the suspect's alibi, and a low level of similarity between the suspect and a facial composite of the perpetrator".192 The phone records and the eyewitness identification are both incriminating evidence against the

183 Simon "A Third View of the Black Box: Cognitive Coherence in Legal Decision Making" 2004 The University Of Chicago Law Review 517 and Charman, Douglas and Mook "Cognitive Bias in Legal Decision Making" 2019 Psychological Science and the Law 30-33.

184 Simon 2004 The University Of Chicago Law Review 517.

185 Charman, Douglas and Mook 2019 Psychological Science and Law 42-45.

186 Simon 2004 The University Of Chicago Law Review 512-513 and Charman, Douglas and Mook 2019 Psychological Science and the Law 30-32.

187 Charman, Douglas and Mook 2019 Psychological Science and Law 42.

188 Simon 2004 The University Of Chicago Law Review 513 and 518.

189 Simon 2004 The University Of Chicago Law Review 516 and Charman, Douglas and Mook 2019 Psychological Science and the Law 41-43.

190 Charman, Douglas and Mook 2019 Psychological Science and the Law 42.

191 Charman, Douglas and Mook 2019 Psychological Science and the Law 42; see also Simon 2004 The University Of Chicago Law Review 516-518.

192 Charman, Douglas and Mook 2019 Psychological Science and the Law 42. 
accused, so they are connected via a positive link. ${ }^{193}$ The alibi and low level of similarity between the accused and the facial composite are both exonerating evidence and are connected via a positive link. ${ }^{194}$ The final step is for the incriminating evidence to be connected to the exonerating evidence via negative links. ${ }^{195}$ Thus, the detective's increased belief in the validity of the phone record evidence increases the cognitive believability of the eyewitness identification evidence and decreases the believability of the suspect's alibi and the relevance of the low similarity to the facial composite. ${ }^{196}$ Over time this becomes a coherent state as the mutually reinforcing or incriminating evidence becomes highly activated, thereby suppressing the contradictory or exonerating evidence. ${ }^{197}$

This implies that as a result of coherence-based reasoning, legal decisionmaking can be construed as a bidirectional process where the evaluation of pieces of evidence integrated together, can affect decision-makers' emerging beliefs concerning the guilt of the accused person and the emerging beliefs equally affect the pieces of evidence that are evaluated. ${ }^{198}$

\section{DEBIASING COGNITIVE SHORTCUTS}

\section{Creating awareness through judicial education and training}

Awareness has been suggested as a possible strategy to avoid or mitigate the effects of heuristics and cognitive bias in judicial decision-making. ${ }^{199}$ Educating judges and magistrates on the causes and effects of the different manifestations of heuristics ${ }^{200}$ could at least raise awareness of the influence of complex mental processes on legal decision-making. However, there are concerns about whether simply creating awareness in this regard is sufficient to avoid or minimise heuristics in judicial decision-making, because heuristics is an automatic or unintended process that occurs in human cognition. 201

As stated in the introduction of this article, there is no empirical evidence to indicate the effect of heuristics and cognitive bias on judges in South Africa. ${ }^{202}$ Education and awareness could, however, stimulate future

193 Ibid.

194 Ibid.

195 Ibid.

196 Ibid.

197 Ibid.

198 Johns https://gacc.nifc.gov/swcc/dispatch_logistics/overhead/imt/documents/what_was_he thinking.pdf 26 and Charman, Douglas and Mook 2019 Psychological Science and the Law 42.

199 Irwin and Real 2016 McGeorge L Rev 10; Edmond and Martire 2019 MLR 657-658 and Greene and Ellis https://www.researchgate.net/publication/229737159_Decision_Making_in Criminal Justice 30.

200 Peer and Gamliel 2013 Court Review 118

201 Greene and Ellis https://www.researchgate.net/publication/229737159_Decision_Making_in Criminal_Justice 30; Peer and Gamliel 2013 Court Review 118.

202 Gravett 2017 The South African Law Journal 53 and Edmond and Martire 2019 MLR 657661. 
research to address this research gap. Section 180 of the South African constitution provides for the consideration of education and training for judicial officers to foster the administration of justice. ${ }^{203}$ Perhaps, through the South African Judicial Education Institute (SAJEI) ${ }^{204}$ education and training on cognitive psychology could be designed. The mandate of the institute includes the following:

"(a) To establish, develop, maintain and provide judicial education and professional training for judicial officers;

(b) To provide entry-level education and training for aspiring judicial officers to enhance their suitability for appointment to judicial office;

(c) To conduct research into judicial education and professional training and to liaise with other judicial education and professional training institutions, persons and organisations in connection with the performance of its functions;

(d) To promote, through education and training, the quality and efficiency of services provided in the administration of justice in the republic;

(e) To promote the independence, impartiality, dignity, accessibility and effectiveness of the courts; and (f) To render such assistance to foreign judicial institutions and courts as
may be agreed upon by the Council."205

The mandate implies that the education and training for judicial officers could include discussions on cognitive psychology. Currently, the institute organises programmes on judicial education and training for newly appointed and existing judicial officers with the aim of sharpening the competence and efficiency of the Bench. ${ }^{206}$ For example, the institute organises the Aspirant Judges Training Course ${ }^{207}$ and the Annual Training for District Court Magistrates. ${ }^{208}$ In addition, the institute electronically publishes the Judicial Education Newsletter that is focused on judicial education and related matters. ${ }^{209}$

Thus, providing awareness of cognitive bias and heuristics through the institute's training programmes, workshops, seminars and/or newsletters, could help judges and other fact-finders to have a better understanding of human cognitive systems and the manifestations of heuristics. It will help judges to become familiar with the effects of heuristics on judicial decisionmakers and it will help to show the inevitability of cognitive biases and the need for appropriate measures to reduce its effects.

203 Mokgoro https://www.sabar.co.za/law-journals/2010/december/2010-december-vol023-no3pp43-48.pdf 46.

204 The institute is established by the South African Judicial Education Institute Act (SAJEI) 14 of 2008.

205 S 5 of the South African Judicial Education Institute Act 14 of 2008.

206 Mokgoro https://www.sabar.co.za/law-journals/2010/december/2010-december-vol023-no3pp43-48.pdf 46.

207 See SAJEI Aspirant Judges Programme https://www.judiciary.org.za/index.php/sajei/ aspirant-judges-programme (accessed 2019-12-23).

208 See SAJEI 2019/2020 Annual Training Schedule for District Magistrate https://www.judiciary.org.za/index.php/sajei/annual-training-schedule-2018-19 (accessed 2019-12-23).

209 SAJEI Judicial Education Newsletter https://www.judiciary.org.za/index.php/sajei/judicialeducation-newsletters (accessed 2019-12-23). 
In summary, "awareness is a sensible first step" amongst other strategies that can be used together to prevent or minimise the effects of heuristics and bias. ${ }^{210}$

\section{Cross-examination}

Heuristics and cognitive bias have the potential to affect not only judicial decision-makers but defence counsel, police officers/investigators and expert witnesses in the legal system. ${ }^{211}$ For example, cognitive shortcuts, such as availability heuristics, confirmation bias and representative heuristic etc can affect the interpretation and evaluation of expert witness testimony and this could have profound effects on judicial decision-makers. ${ }^{212}$ Thus, exposing bias or potential bias by cross-examination is critical. Crossexamination has two purposes "first, to elicit evidence which supports the cross-examiner's case; and secondly, to cast doubt on the evidence given for the opposing party". ${ }^{213}$ In addition, cross-examination will test the credibility and veracity of the witness and/or evidence presented in court. ${ }^{214}$

In an adversarial system judges have the responsibility to be impartial and must not be seen to be too involved in the cross-examination of witnesses in order to prevent any allegations of unfairness. ${ }^{215}$ They must focus on the interpretation of the law and carefully consider the facts, evidence and arguments presented by the prosecution and the defence. ${ }^{216}$ However, judges can allow cross-examination questions used to interrogate expert witnesses, investigators and accused persons on the manifestations of cognitive bias where applicable. ${ }^{217}$ Such questions relating to (1) whether the witness is familiar with what cognitive bias means in the context of their testimony; (2) whether the witness considered contradictory evidence (i.e., categorical judgements or statistical/scientific evidence, where relevant) refuting the guilty hypothesis; ${ }^{218}$ (3) whether the witness is familiar with the effects of cognitive bias on judicial decision-makers.

The kind of cross-examination questions referred to above, could be powerful tools available to cross-examiners to expose manifestations of cognitive bias. Cross-examination questions such as these, could be of

210 Edmond and Martire 2019 MLR 658.

211 Charman, Douglas and Mook 2019 Psychological Science and the Law 32 and 38.

212 Saks and Kidd 1980-1981 Law and Society Review 137-139; Rassin et al $2010 \mathrm{~J}$. Investig. Psych. Offender Profil 231-232 and Rachlinski 2000 Oregon Law Review 85-86.

213 Zeffertt and Paizes The South African Law of Evidence 3ed (2017) 1030 and Vettori and De Beer "The Consequences of Pleading a Non-Admission" 2013 De Jure http://www.scielo.org.za/pdf/dejure/v46n2/15.pdf (accessed 2020-01-14) 617.

214 Ibid.

215 S v Le Grange supra par 21.

$216 S$ v Le Grange supra par 21; see also Bernert v Absa Bank Ltd supra par 31; Dube $v$ The State supra 28; Sepheka v Du Point Pioneer supra 336; $S$ v Roberts supra par 26. See also Gravett 2017 The South African Law Journal 75; Irwin and Real 2016 McGeorge L Rev 10 and Beecher-Monas 2003 L Rev MSU-DCL 989-991.

217 Charman, Douglas and Mook 2019 Psychological Science and the Law 36.

218 Rassin "Reducing Tunnel Vision With a Pen-and-Paper Tool For The Weighting of Criminal Evidence" 2018 Journal of Investigative Psychology and Offender Profiling 11-7. 
significant assistance to the court in its attempts to curb the effects of cognitive bias on judicial decision-making.

\section{Replacement}

Replacement strategy has been suggested as effective in avoiding and mitigating bias. ${ }^{219}$ This strategy involves replacing a judge who is likely to be biased when making decisions.220 Pretrial detention hearings (or bail hearings) have been identified as possible triggers of confirmation bias. The appointment of a different judge for the main hearing, instead of the same judge involved in the pretrial hearing, could mitigate the effect of bias in judicial decisions. ${ }^{221}$

\section{CONCLUSION}

This article briefly examines how heuristics, which have an automatic or unconscious influence on human reasoning, can affect judicial decisionmaking. The discussion above briefly indicate how availability heuristics, confirmation bias, egocentric bias, anchoring, hindsight bias, framing and representativeness can distort inferences and interpretations that are made either at the pretrial, hearing, ruling or sentencing process of a criminal case. The article emphasises that the different manifestations of heuristics pose a potentially serious risk to the quality and objectivity of any criminal case, despite the professional legal training and experience of judges and magistrates. Therefore, suggestions on how best to avoid and minimise the effects of cognitive shortcuts are suggested. These include creating awareness raising, cross-examination and replacement.

The article recognises that heuristics affecting judicial decisions are not well known in South Africa, but the situations that have been illustrated in existing research shows a possibility of occurrence in any jurisdiction, including South Africa.

Lord Neuberger states that judges are human and therefore inevitably susceptible to cognitive bias. ${ }^{222}$ One study summarises its conclusions as follows:

"Judges, it seems, are human. They appear to fall prey to the same cognitive illusions that psychologists have identified among laypersons and other professionals .... Even if judges are free from prejudice against either litigant, fully understand the relevant law, know all of the relevant facts, and can put their personal politics aside, they might still make systematically erroneous decisions because of the way they - like all humans - think". ${ }^{223}$

219 Edmond and Martire 2019 MLR 658-659.

220 Ibid.

221 Lidén et al 2018 Psychology, Crime and Law 22 and Edmond and Martire 2019 MLR 658659.

222 Lord Neuberger "'Judge not, that ye be not judged': Judging Judicial Decision-Making" 2015 F A Mann Lecture https://www.supremecourt.uk/docs/speech-150129.pdf (accessed 202001-16).

223 Guthrie et al 2002 Judicature 144,50 , itself abstracting the authors' article "Inside the Judicial Mind" 200186 Cornell L Rev 777. 